\title{
PENGARUH MEDIA OVERHEAD PROJECTOR DAN PEMBERIAN LEMBAR KERJA SISWA TERHADAP HASIL BELAJAR PENDIDIKAN PANCASILA DAN KEWARGANEGARAAN DAN BAHASA INDONESIA
}

\author{
La Maskone \\ Dinas Pendidikan Kota Bau-bau, Kendari
}

\begin{abstract}
Improving educational quality is a continous procceses done by teachers. One of the strategy to improve the quality is to improve substance or content delivery. This study attempt to elaborate the effect of using overhead projector (OHP) media in lecturing method for Civic and Bahasa Indonesia for high school students. Experiment approach was used to answer research questions. Factorial design was selected to reveal the research outcomes. The result showed that there was significant impact of using OHP to support learning process on Civic and Bahasa Indonesia.
\end{abstract}

Keywords: bahasa Indonesia, civic, overhead projector

Era globalisasi merupakan peluang sekaligus tantangan bagi bangsa Indonesia dalam upaya meningkatkan kualitas Sumber Daya Manusia (SDM) yang mampu bertanding dan bersanding dengan bangsa lain. Arus globalisasi dan informasi telah mengalir keseluruh kehidupan dan membawa dampak bagi manusia yang sebelumnya tidak terduga. Mengantisipasi perubahan dan perkembangan yang terjadi, aspek kualitas yang perlu dibangun tidak terbatas pada fisik dan mental kecerdasan saja, tetapi meliputi kemampuan siswa menepis pengaruh buruk perubahan dan perkembangan tersebut.

Berkaitan dengan konsep belajar, Burto (1994) mengartikan sebagai berikut: "Learning is a change in the individual due to instruction of that individual and his environment, which fells a need and makes him more capable of dealing adequeately with his environment". Ada kata kunci perubahan tingkah laku pada anak didik yang terlibat dalam proses belajar secara individual. Perubahan tersebut mencakup aspek pengetahuan, keterampilan, dan sikap.

Sesuai tuntutan perubahan maka proses pembelajaran harus secara terus menerus ditingkatkan kualitasnya, baik secara isi materi maupun metode pembelajarannya. Guru memiliki peran yang sangat besar dalam proses pembelajaran untuk dapat selalu memperbaiki kualitas, baik secara isi materi maupun dalam cara penyampaian. Berbagai strategi dan penggunaan alat bantu penyampaian pelajaran dapat dicoba untuk diterapkan dalam rangka mencapai dan menemukan kegiatan pembelajaran yang paling efektif.

Perbaikan pembelajaran terus menerus harus menjadi perhatian guru. Kenyataan yang terjadi dalam proses pembelajaran Pendidikan Pancasia dan Kewarganegaraan (PPKn) dan Bahasa Indonesia di Sekolah Menengah Umum sekarang ini masih jauh dari harapan dan perhatian khusus para guru. Mata pelajaran tersebut dianggap sebagai pelengkap mata pelajaran lainnya, bukan suatu kebutuhan yang mewarnai pola hidup.

Untuk mengatasi masalah tersebut maka perlu adanya Pembelajaran PPKn yang memperhatikan sejumlah variabei seperti metode dan media pembelajaran dari berbagai fasilitas. 
Apabila proses pembelajaran tersebut diselenggarakan secara formal di sekolah-sekolah, dimaksudkan untuk mengarahkan perubahan pada diri siswa secara terencana, baik dalam aspek pengetahuan, keterampilan maupun sikap.

Dari gambaran masalah yang diungkapkan di atas, terlihat pentingnya alternatif pembelajaran yang terkait dunia nyata di sekolah. Alternatif yang dimaksud yaitu sistem pembelajaran yang dapat meningkatkan pemahaman, keterampilan berfikir kritis, dan kemampuan mengaplikasikan teori dan konsep-konsep yang telah dipahami, untuk memudahkan pembelajaran dalam dunia nyata.

Menurut Reigeluth dalam Degeng (1989) pada hakekatnya hanya variabel metode pembelajaran yang berpeluang untuk dimanipulasi. Karena metode yang tepat dengan memperhatikan kondisi yang ada akan dapat meningkatkan hasil belajar.

Senada dengan Reigeluth, Degeng (2001) berpendapat bahwa belajar menjadi mudah dan lebih menyenangkan bagi siswa apabila dilakukan dengan metode yang lebih efektif, efisien dan memiliki daya tarik tinggi. Belajar dapat diartikan sebagai proses perubahan tingkah laku pada diri sendiri disebabkan adanya interaksi antara individu, dan individu dengan lingkungannya.

Belajar menjadi lebih mudah dan menyenangkan apabila dipergunakan alat bantu yang akan memperkaya interaksi antara pengajar dan pembelajar di dalam kelas. Untuk sekolah menengah di Indonesia, terutama di wilayah luar P. Jawa, terdapat keterbatasan atas pilihan alat bantu yang dapat digunakan di dalam kelas karena keterbatasan peralatan dan infrastruktur. Untuk sekolah-sekolah tersebut penggunaan overhead projector (OHP) dianggap masih cukup relevan dalam membantu proses pembelajaran.

Berkaitan dengan penggunaan OHP tersebut muncul pertanyaan sebagai berikut.

1. Apakah terdapat perbedaan hasil belajar siswa pada mata pelajaran PPKn dan Bahasa Indonesia Siswa Kelas XI SMAN 3 dan SMAN 4 Bau-Bau antara kelompok pembelajaran yang dikenal metode ceramahber-OHP dan siswa yang dikenal metode ceramah tanpa OHP?.

2. Apakah ada perbedaan yang signifikan hasil belajar PPKn dan Bahasa Indonesia siswa yang dikenal metode ceramah disertai Lembar Kegiatan Siswa (LKS) dengan siswa yang dikenal metode ceramah tanpa disertai LKS?.

3. Apakah ada interaksi antara metode ceramah bermedia OHP dan metode ceramah disertai LKS terhadap hasil belajar PPKn dan Bahasa Indonesia?

Untuk menjawab pertanyaan tersebut dilakukan penelitian dengan tujuan sebagai berikut.

1. Untuk mengetahui perbedaan hasil belajar siswa pada mata pelajaran PPKn dan Bahasa Indonesia Siswa Kelas XI SMAN 3 dan SMAN 4 Bau-Bau antara kelompok pembelajaran ceramahber-OHP dan ceramah tanpa OHP.

2. Untuk mengetahui perbedaan yang signifikan hasil belajar PPKn dan Bahasa Indonesia siswa metode ceramah disertai LKS dengan ceramah tanpa disertai LKS.

3. Untuk mengetahui interaksi antara metode ceramah bermedia OHP dan metode ceramah disertai LKS terhadap hasil belajar PPKn dan Bahasa Indonesia.

Adapun manfaat yang diharapkan dari penelitian ini, diantaranya adalah dapat mendorong para guru untuk memanfaatkan dan menggunakan media pembelajaran yang tersedia, terutama media OHP dan LKS dengan sebaik-baiknya demi perbaikan proses pembelajaran dan demi peningkatan hasil belajar peserta didik.

Melalui penelitian ini pula diharapkan memperoleh informasi-informasi nyata (positif) 
mengenai manfaat penerapan media OHP dan LKS dalam proses pembelajaran PPKn dalam peningkatan hasil belajar peserta didik, sehingga dapat dijadikan bahan pertimbangan dalam menentukan kebijakan pengembangan kurikulum pengajaran, khususnya pemenuhan kebutuhan media pengajaran dalam strategi penyampaian materi pengajaran.

\section{METODOLOGI}

Penelitian ini termasuk jenis penelitian eksperimental sesungguhnya, dengan melibatkan empat (4) variabel bebas. Dengan rancangan ini, akan diperoleh perbandingan nilai pretes dan postest yang menunjukan besarnya perubahan yang terjadi pada variabel terikat selama perlakuan bekerja.

Metode pembelajaran yang diobservasi mencakup metode ceramah disertai media OHP dan LKS, metode ceramah disertai OHP tanpa LKS, metode ceramah tanpa OHP disertai LKS, dan metode ceramah tanpa OHP dan tanpa LKS, untuk mata pelajaran PPKn dan Bahasa Indonesia.Sehingga terdapat 8 (delapan) perlakuan, empat perlakuan pada bidang studi PPKn dan empat perlakuan pada bidang studi Bahasa Indonesia sebagaimana tertera pada Tabel 1.

Tabel 1. Rancangan Eksperimen Pengajaran Pada Kelas Dengan Delapan Kelompok Perlakuan

\begin{tabular}{|c|c|c|c|}
\hline \multicolumn{2}{|c|}{ PELAJARAN } & \multicolumn{2}{|c|}{ METODE CERAMAH (C) } \\
\hline \multirow{3}{*}{ PPKn (Kn) } & \multirow{3}{*}{$\begin{array}{c}\text { LKS } \\
\text { (LK) } \\
\text { NON } \\
\text { LKS } \\
\text { (NLK) }\end{array}$} & $\mathrm{OHP}(\mathrm{OH})$ & $\begin{array}{c}\text { NON OHP } \\
(\mathrm{NOH})\end{array}$ \\
\hline & & $\begin{array}{c}\mathrm{Kn} \text { LK.OH } \\
\text { (R 1) }\end{array}$ & $\begin{array}{c}\mathrm{Kn} \text { LK.NOH } \\
(\mathrm{R} 2)\end{array}$ \\
\hline & & $\begin{array}{l}\text { Kn NLK.OH } \\
\text { (R 2) }\end{array}$ & $\begin{array}{c}\text { Kn NLK.NOH } \\
\text { (R 4) }\end{array}$ \\
\hline \multirow{2}{*}{$\begin{array}{c}\text { BAHASA } \\
\text { INDONESIA } \\
\text { (BI) }\end{array}$} & $\begin{array}{l}\text { LKS } \\
\text { (LK) }\end{array}$ & $\begin{array}{l}\text { BI LK. OH } \\
\text { (R 5) }\end{array}$ & $\begin{array}{c}\text { BI LK. NOH } \\
(\text { R 7) }\end{array}$ \\
\hline & $\begin{array}{l}\text { NON } \\
\text { LKS } \\
\text { (NLK) }\end{array}$ & $\begin{array}{l}\text { BI LK. OH } \\
\quad(\mathrm{R} 6)\end{array}$ & $\begin{array}{l}\text { BI NLK. NOH } \\
\quad(R \text { 8) }\end{array}$ \\
\hline
\end{tabular}

Sebelum kegiatan pengajaran kedelapan kelompok diberi pretes (T1), untuk mengukur tingkat kemampuan awal dari subyek. Setelah proses pembelajaran kedelapan kelompok diberikan postes (T2), untuk mengukur variabel bebas. Rancangan eksperimen dengan pretes dan postes dengan perlakuan tertera pada Tabel 2 .

Tabel 2. Prosedur Eksperimental dengan Pretes dan Postes Kelompok dengan Perlakuan

\begin{tabular}{lccc}
\hline \multicolumn{1}{c}{ KELOMPOK } & PRETES & TREATMENT & POSTES \\
\hline Kelompok Eksperimen I (R1) & T1 & X1 & T2 \\
Kelompok Eksperimen II (R2) & T1 & X2 & T2 \\
Kelompok Eksperimen III (R3) & T1 & X3 & T2 \\
Kelompok Eksperimen IV (R4) & T1 & X4 & T2 \\
Kelompok Eksperimen V (R5) & T1 & X5 & T2 \\
Kelompok Eksperimen VI (R6) & T1 & X6 & T2 \\
Kelompok Eksperimen VII (R7) & T1 & X7 & T2 \\
Kelompok Eksperimen VIII (R8) & T1 & X8 & T2 \\
\hline
\end{tabular}


Tempat penelitian dilakukan di SMAN 3 dan SMAN 4 Bau-Bau dengan waktu pelaksanaan penelitian pada semester kedua tahun pelajaran 2007/2008, yaitu bulan Januari hingga Juni 2008. Adapun pelaksanaan kegiatan belajar mengajar dilaksanakan pada bulan Februari, Maret, dan April 2008.

Untuk masing-masing sekolah diambil dua kelas dengan jumlah 40 siswa/kelas, sehingga keseluruhan subyek berjumlah 160 siswa.

Secara keseluruhan ada lima variabel dalam penelitian ini, yaitu empat variabel bebas dan satu terikat, sebagai berikut: (1) metode ceramah disertai OHP dan LKS (X1), (2) metode ceramah disertai OHP tanpa LKS (X2), (3) metode ceramah dengan LKS tanpa OHP(X3), (4) metode ceramah tanpa OHP dan tanpa LKS(X4), dan (5) Hasil Belajar (Y).

Menurut Arikunto (1998) "Pada dasarnya terdapat dua macam instrument penelitian, yakni instrument yang berbentuk tes dan non test. Instrument test berbentuk test tulis dan test lisan, sedang instrument non test seperti angket, kuesioner, observasi, wawancara". Instrument yang digunakan dalam penelitian ini adalah instrument test tertulis berbentuk pilihan ganda dengan 4 pilihan jawaban. Tes obyektif ini dimaksudkan agar hasil dari jawaban responden benar-benar mencerminkan hasil yang dapat terukur secara obyektif, artinya tidak memiliki pengertian ganda dari jawaban yang diberikan responden.

Soal-soal yang digunakan untuk instrumen tes ini, diambilkan dari soal-soal tes semester atau soal-soal tes catur wulan yang telah dipergunakan pada tahun-tahun lalu, yang relevan dengan pokok bahasan yang sedang diteliti, baik untuk bidang studi PPKn maupun Bahasa Indonesia. Juga diambilkan dari soal-soal LKS PPKn dan Bahasa Indonesia yang sedang menjadi materi kajian penelitian ini sehingga instrument tes tersebut tidak perlu dilakukan uji validitas dan reliabilitasnya. Instrumen tes ini digunakan dalam dua kegiatan, yaitu untuk pretes dan postes.

Pengumpulan data dalam penelitian ini adalah menggunakan teknik tes (Sudjana, 1989), dalam bentuk test tertulis berbentuk pilihan ganda dengan 4 pilihan jawaban, Jumlah soal 40 item dengan alokasi waktu 60 menit, siswa menjawab benar nilai 2,5, berarti nilai tertinggi 100. Teknik analisis data yang digunakan dalam penelitian ini adalah analisis varians 2 faktor.Subyek penelitian dibagi 4 kelompok perlakuan, seluruhnya terdapat 4 sel yang masing-masing sel terdiri atas 40 subyek. Sel inidapat digambarkan sebagaimana pada Tabel 3.

Tabel 3. Kelompok Perlakuan

\begin{tabular}{|c|c|c|c|}
\hline \multirow{2}{*}{\multicolumn{2}{|c|}{$\begin{array}{l}\text { Pembelajaran } \\
\text { PPKn/BIN }\end{array}$}} & \multicolumn{2}{|c|}{ Ceramah + OHP (A) } \\
\hline & & $\mathrm{COH}(\mathrm{A} 1)$ & $\mathrm{CNOH}(\mathrm{A} 2)$ \\
\hline Ceramah & CLK (BI) & A1 B1 (1) & A2 B1 (3) \\
\hline $\operatorname{LKS}(B)$ & CNLK (B2) & A1 B2 (2) & A2 B2 (4) \\
\hline
\end{tabular}

Keterangan :

Kelompok PPKn:

1. Pembelajaran PPKn dengan metode ceramah disertai OHP dan LKS.

2. Pembelajaran PPKn dengan metode ceramah disertai OHP tanpaLKS.

3. Pembelajaran PPKn dengan metode ceramah disertai LKS tanpaOHP.

4. Pembelajaran PPKn dengan metode ceramah tanpa disertai OHPdan LKS. 
Kelompok Bahasa Indonesia (B1):

1. Pembelajaran B1 dengan metode ceramah disertai OHP dan LKS.

2. Pembelajaran B1 dengan metode ceramah disertai OHP tanpa LKS.

3. Pembelajaran B1 dengan metode ceramah disertai LKS tanpa OHP.

4. Pembelajaran B1 dengan metode ceramah tanpa disertai OHP dan LKS.

HASIL

Analisis data dilakukan dengan Analisis varians Dua Faktor (ANOVA Dua Faktor). Dalam ANOVA Dua Faktor ini ada tiga asumsi yang harus dipenuhi, yaitu independent, homogenitas, varians dan normalitas. Asumsi independent telah dilaksanakan pada saat memilih siswa yang termasuk dalam kelompok perlakuan yang telah ditentukan.

Hasil analisis kenormalan dapat dilihat pada Tabel 4 yang menunjukkan bahwa hasil belajar PPKn siswa berdistribusi normal.

Tabel 4. Ringkasan hasil Uji Normalitas Hasil Belajar PPKn Siswa

\begin{tabular}{ccccc}
\hline $\begin{array}{c}\text { Hasil } \\
\text { Belajar }\end{array}$ & $\begin{array}{c}\text { Statistik } \\
\text { Kolmogorov- } \\
\text { Smirnov }\end{array}$ & Signifikansi & Alpha & Keterangan \\
\hline $\begin{array}{c}\text { Ceramah } \\
\& \text { OHP }\end{array}$ & 0,083 & $0,200>0,05$ & 0,05 & Normal \\
$\begin{array}{c}\text { Ceramah } \\
\& \text { OHP }\end{array}$ & 0,102 & $0,200>0,05$ & 0,05 & Normal \\
$\begin{array}{c}\text { Ceramah } \\
\& \text { LKS }\end{array}$ & 0,096 & $0,200>0,05$ & 0,05 & Normal \\
$\begin{array}{c}\text { Ceramah } \\
\text { Non LKS }\end{array}$ & 0,117 & $0,182>0,05$ & 0,05 & Normal \\
\hline
\end{tabular}

\section{Analisis Hipotesis Penelitian Pertama}

Hipotesis penelitian pertama berbunyi ada perbedaan yang signifikan antara hasil belajar PPKn siswa metode ceramah bermedia OHP dan siswa metode ceramah tanpa media OHP. Langkah pengujiannya adalah sebagai berikut.

$\mathrm{Ho}$ : tidak ada perbedaan yang signifikan hasil belajar PPKn siswa metode ceramah bermedia OHP dan siswa metode ceramah tanpa media OHP.

$\mathrm{Hi} \quad$ : ada perbedaan yang signifikan hasil belajar PPKn siswa metode ceramah bermedia OHP dan siswa metode ceramah tanpa media OHP.

Tabel 5. Ringkasan Hasil Analisis Hasil Belajar PPKn Siswa

\begin{tabular}{lcccl}
\hline \multicolumn{1}{c}{ Variabel } & Statistik & Signifikansi & Alpha & Keterangan \\
\hline OHP \& Non OHP & 4,834 & $0,029<0,05$ & 0,05 & Berbeda \\
LKS \& Non LKS & 125,491 & $0,000<0,05$ & 0,05 & Berbeda \\
Interaksi OHP dan LKS & 24,732 & $0,000<0,05$ & 0,05 & Ada Interaksi \\
\hline
\end{tabular}


Dari tabel 5 menunjukan nilai statistik $F=4,834$ dan nilai signifikansinya adalah 0,029 0,05. Ho ditolak. Artinya ada perbedaan yang signifikan hasil belajar PPKn siswa metode ceramah bermedia OHP dan siswa yang dikenal metode ceramah tanpa media OHP.

\section{Analisis Hipotesis Penelitian Kedua}

Hipotesis penelitian kedua berbunyi ada perbedaan yang signifikan hasil belajar PPKn siswa metode ceramah disertai LKS dan siswa metode ceramah tanpa disertai LKS.

$\mathrm{Ho}$ : tidak ada perbedaan yang signifikan hasil belajar PPKn siswa metode ceramah disertai LKS dan siswa metode ceramah tanpa disertai LKS.

$\mathrm{Hi}$ : ada perbedaan yang signifikan hasil belajar PPKn siswa metode ceramah disertai LKS dan siswa metode ceramah tanpa disertai LKS.

Tabel 5 menunjukan nilai statistik $F=125,491$ dan nilai signifikansinya adalah 0,000 0,05. Ho ditolak. Artinya ada perbedaan yang signifikan hasil belajar PPKn siswa metode ceramah disertai LKS dan siswa metode ceramah tanpa disertai LKS.

\section{Analisis Hipotesis Penelitian Ketiga}

Hipotesis penelitian ketiga berbunyi terdapat interaksi antara metode ceramah bermedia OHP dan metode ceramah disertai LKS dalam hasil belajar PPKn siswa.

$\mathrm{Ho}$ : tidak ada interaksi antara metode ceramah bermedia OHP dan metode ceramah disertai LKS dalam hasil belajar PPKn siswa.

$\mathrm{Hi}$ : ada interaksi antara metode ceramah bermedia OHP dan metode ceramah disertai LKS dalam hasil belajar PPKn siswa.

Pada tabel 5 menunjukan nilai statistik $F=24,732$ dan nilai signifikansinya adalah $0,000<$ 0,05 . Ho ditolak, Artinya ada interaksi antara metode ceramah bermedia OHP dan metode ceramah disertai LKS dalam hasil belajar PPKn siswa.

Tabel 6. Ringkasan hasil Uji Normalitas Hasil Belajar Bahasa Indonesia Siswa

\begin{tabular}{ccccc}
\hline $\begin{array}{c}\text { Hasil } \\
\text { Belajar }\end{array}$ & $\begin{array}{c}\text { Statistik } \\
\text { Kolmogorov- } \\
\text { Smirnov }\end{array}$ & Signifikansi & Alpha & Keterangan \\
\hline $\begin{array}{c}\text { Ceramah } \\
\text { \&OHP }\end{array}$ & 0,092 & $0,200>0,05$ & 0,05 & Normal \\
$\begin{array}{c}\text { Ceramah } \\
\text { Non OHP }\end{array}$ & 0,061 & $0,200>0,05$ & 0,05 & Normal \\
$\begin{array}{c}\text { Ceramah } \\
\text { \&LKS }\end{array}$ & 0,083 & $0,200>0,05$ & 0,05 & Normal \\
$\begin{array}{c}\text { Ceramah } \\
\text { Non LKS }\end{array}$ & 0,103 & $0,200>0,05$ & 0,05 & Normal \\
\hline
\end{tabular}

\section{Pengujian Hipotesis Penelitian Keempat}

Hipotesis penelitian keempat berbunyi ada perbedaan yang signifikan hasil belajar Bahasa Indonesia siswa metode ceramah bermedia OHP dan siswa metode ceramah tanpa media OHP. Langkah pengujiannya adalah sebagai berikut. 
Ho : tidak ada perbedaan yang signifikan hasil belajar Bahasa Indonesia siswa metode ceramah bermedia OHP dan tidak

$\mathrm{Hi}$ : ada perbedaan yang signifikan hasil belajar Bahasa Indonesia siswa metode ceramah bermedia OHP dan tidak

Tabel 7. Ringkasan Hasil Analisis Hasil Belajar Bahasa Indonesia

\begin{tabular}{ccccc}
\hline Variabel & $\begin{array}{c}\text { Statistik } \\
\text { F }\end{array}$ & Signifikansi & Alpha & Keterangan \\
\hline OHP \& Non OHP & 7,137 & $0,008<0,05$ & 0,05 & Berbeda \\
LKS \& Non LKS & 7,631 & $0,006<0,05$ & 0,05 & Berbeda \\
Interaksi OHP & 0,178 & $0,674<0,05$ & 0,05 & $\begin{array}{c}\text { Tidak ada } \\
\text { Interaksi } \\
\text { dan LKS }\end{array}$ \\
\hline
\end{tabular}

Pada tabel 7 menunjukan nilai statistik $F=7,137$ dan nilai signifikansinya adalah 0,008 $<0,05$. Ho ditolak. Artinya ada perbedaan yang signifikan pada hasil belajar Bahasa Indonesia siswa metode ceramah bermedia OHP dan tidak.

\section{Pengujian Hipotesis Penelitian Kelima}

Hipotesis penelitian kelima berbunyi ada perbedaan yang signifikan hasil belajar Bahasa Indonesia siswa metode ceramah disertai LKS dan siswa metode ceramah tanpa disertai LKS.

$\mathrm{Ho}$ : tidak ada perbedaan yang signifikan hasil belajar Bahasa Indonesia siswa metode ceramah disertai LKS dan siswa metode ceramah tanpa disertai LKS.

$\mathrm{Hi}$ : ada perbedaan yang signifikan hasil belajar Bahasa Indonesia siswa metode ceramah disertai LKS dan siswa metode ceramah tanpa disertai LKS.

Pada tabel 7 menunjukan nilai statistic $F=7,631$ dan nilai signifikansinya adalah $0,006<$ 0,05 . Ho ditolak. Artinya ada perbedaan yang signifikan hasil belajar Bahasa Indonesia siswa metode ceramah disertai LKS dan siswa metode ceramah tanpa disertai LKS.

\section{Pengujian Hipotesis Penelitian Keenam}

Hipotesis penelitian keenam berbunyi interaksi antara metode ceramah bermedia OHP dan metoda ceramah disertai LKS dalam hasil belajar Bahasa Indonesia siswa.

$\mathrm{Ho}$ : tidak ada interaksi antara metode ceramah bermedia OHP dan metode ceramah disertai LKS dalam hasil belajar Bahasa Indonesia siswa.

$\mathrm{Hi}$ : ada interaksi antara metode ceramah bermedia OHP dan metode ceramah disertai LKS dalam hasil belajar Bahasa Indonesia siswa.

Pada Tabel 7 menunjukan nilai statistik $F=0,178$ dan nilai signifikansinya adalah $0,674<$ 0,05 . Ho diterima. Artinya tidak ada interaksi antara metode ceramah bermedia OHP dan metode ceramah disertai LKS dalam hasil belajar Bahasa Indonesia siswa.

\section{PEMBAHASAN}

\section{Pembahasan Hasil Analisis Hipotesis Penelitian Kesatu}

Kesimpulan dari analisis yang telah diuraikan dalam bab sebelumnya adalah ada perbedaan yang signifikan hasil belajar PPKn siswa metode ceramah bermedia OHP dan siswa metode 
ceramah tanpa media OHP. Dengan kata lain, penggunaan media OHP terbukti mempengaruhi hasil belajar PPKn siswa. Hal ini sesuai dengan pendapat yang menyatakan bahwa penggunaan media pembelajaran pada umumnya memang dimaksudkan untuk membantu proses komunikasi dengan siswa, termasuk media OHP (Briggs, 1986). Bahkan Setijadi (1987) menyatakan OHP adalah alat Bantu pembelajaran karena didesain secara khusus untuk digunakan guru di depan kelas.

Sebagai alat. Bantu yang diharapkan dapat meningkatkan hasil belajar, ternyata OHP memberi pengaruh positif terhadap hasil belajar PPKn siswa. Pengaruh positif ini dimugkinkan karena OHP dapat memperjelas dan memperlancar pembelajaran, melengkapi indera pendengaran siswa dalam menangkap pesan, mengurangi salah interpretasi, memberi kesan lebih mendalam (Harun, 1984), memberi kesempatan lebih besar bagi siswa untuk mencatat, dan memberi variasi pengajaran.

Materi pembelajaran PPKn sendiri diarahkan untuk membekali siswa dengan nilai-nilai dan budi pekerti luhur Pancasila, pengetahuan mengenai hubungan warganegara dengan negara, serta pemahaman tentang bela negara. Beberapa materi ini akan lebih mudah disampaikan melalui metode ceramah karena lebih bersifat informatif. Namun, penggunaan metode ceramah itu akan terbantu dengan OHP yang dapat membantu siswa dalam mencatat materi bahasan, memberi visualisasi yang dapat mendukung uraian lisan guru, serta memberi variasi proses pembelajaran tersebut agar siswa tidak mengantuk dan kehilangan konsentrasi belajar.

\section{Pembahasan Hasil Analisis Hipotesis Penelitian Kedua}

Hasil analisis menunjukan bahwa ada perbedaan yang signifikan hasil belajar PPKn siswa metode ceramah disertai LKS dan siswa metode ceramah tanpa disertai LKS. Dengan kata lain, penelitian ini membuktikan bahwa penggunaan LKS dengan metode ceramah mempengaruhi hasil belajar PPKn siswa. Lebih lanjut ditunjukan bahwa pengaruh penggunaan LKS dalam pembelajaran PPKn bersifat positif. Hasil ini sesuai dengan pendapat Gerlach (1971) yang menyatakan bahwa LKS mempunyai peranan amat penting dalam upaya mencapai tujuan pembelajaran.

Pengaruh Positif penggunaan LKS ini dapat dijelaskan dari pemahaman bahwa unsur utama strategi pembelajaran adalah terjalinnya interaksi positif guru-siswa, sifat interaksi yang memang terbangun melalui penggunaan LKS. Selama ini, LKS sudah menjadi salah satu alternatif dalam strategi belajar mengajar PPKn yang dilaksanakan di sekolah. LKS berfungsi sebagai bahan arahan kegiatan siswa dalam mengikuti proses pembelajaran dan sebagai buku catatan siswa. LKS juga menjadi prasarana komunikasi yang menungkinkan guru memberitahukan hasil kerja siswa dalam mengerjakan latihan, dan siswa menjadi tahu telah mencapai tujuan pembelajaran atau belum.

LKS terutama digunakan untuk mengembangkan keterampilan proses dan membangkitkan minat terhadap alam sekitar (Darmojo \& Kaligis, 1993). Di sisi lain, siswa umumnya sangat senang menggunakan LKS (Nur, 1994). Bila LKS mampu membangkitkan rasa ingin tahu dan mengembangkan keterlibatan siswa, maka hal ini akan menjadi prasyarat yang secara signifikan mempengaruhi pencapaian hasil belajar yang optimal. Penggunaan metode ceramah pada mata pelajaran PPKn ini akan terbantu dengan LKS yang dapat membentu siswa mencatat materi bahasan, mengulang-ulangnya, serta memberi kesempatan siswa terlibat lebih aktif dalam proses pembelajaran tersebut.

\section{Pembahasan Hasil Analisis Hipotesis Penelitian Ketiga}

Ada interaksi antara metode ceramah bermedia OHP dan metode ceramah disertai LKS dalam hasil belajar PPKn siswa (sesuai dengan hipotesis ketiga). Hasil analisis ini memperkuat hasil 
analisis hipotesis penelitian kesatu dan kedua yang telah disampaikan di atas, karena menyimpulkan bahwa hasil belajar PPKn siswa dipengaruhi penggunaan media OHP dan atau LKS dalam pembelajaran PPKn. Dari uraian dari sub bab sebelumnya juga telah diketahui bahwa media OHP dan atau LKS sama-sama berpengaruh baik terhadap hasil belajar PPKN siswa.

Hasil analisis juga menunjukan bahwa media OHP atau pemberian LKS yang digunakan dalam metode ceramah untuk pembelajaran PPKn ternyata sesuai pernyataan bahwa media berperan sebagai alat yang dapat digunakan untuk memperlancar komunikasi/pembelajaran. Kesimpulan ini dapat dipahami karena penggunaan media OHP dan atau LKS tentunya telah mempengaruhi suasana belajar siswa. Bila semula mereka hanya diharuskan menyimak penuturan lisan guru dalam menerangkan pokok bahasan dalam pelajaran PPKn, dengan adanya OHP dan atau LKS, siswa mendapatkan variasi suasana dan kegiatan dalam proses pembelajaran mereka. Adanya variasi ini memungkinkan terjadinya peningkatan minat siswa (Bruner dalam Prayitno, 1989; Sudjana, 1990), dan pengalaman konkrit yang memudahkan siswa belajar (Fleming \& Levie, 1978). Dengan alat bantu tersebut juga dapat meningkatkan ide atau gagasan yang bersifat konseptual yang dapat mengurangi salah interpretasi siswa dalam mempelajari PPKn, meningkatkan minat siswa mempelajari materi, memberi pengalaman yang merangsang aktivitas diri, dan menjadikan proses belajar mendalam (Heinik, Molenda, \& Russel, 1982; Sudjana, 1990). Karena terbukti berpengaruh secara signifikan, maka dapat dikatakan bahwa media OHP dan LKS yang dimaksudkan sebagai media pendidikan ini dapat digunakan untuk mengefektifkan komunikasi dan interaksi guru-siswa seperti yang dikemukakan Hamalik (1989), dalam pembelajaran PPKn.

\section{Pembahasan Hasil Analisis Hipotesis Penelitian Keempat}

Ada perbedaan yang signifikan hasil belajar Bahasa Indonesia siswa metode ceramah bermedia OHP dan siswa metode ceramah tanpa media OHP. Dengan kata lain, penggunaan media OHP terbukti mempengruhi hasil belajar Bahasa Indonesia siswa. Sesuai dengan pada mata pelajaran PPKn, penggunaan media pembelajaran, termasuk OHP memang dimaksudkan untuk membantu proses komunikasi dengan siswa (Briggs, 1986), dan alat bantu pembelajaran bagi guru di depan kelas (Setijadi 1987).

Sama dengan pada pelajaran PPKn, ternyata OHP memberi pengaruh positif terhadap hasil belajar Bahasa Indonesia siswa seperti yang ditunjukan dalam Tabel 5. Sama dengan pada pembelajaran PPKn, pengaruh positif ini dimungkinkan karena OHP dapat memperjelas dan memperlancar pembelajaran, melengkapi indera pendengaran siswa dalam menangkap pesan, mengurangi salah interprestasi, memberi kesan lebih mendalam,dan karenanya dapat membangkitkan motivasi siswa, serta memberi kesempatan lebih besar bagi siswa untuk mencatatdan memberi variasi pengajaran.

Dikaitkan dengan mata pelajaran Bahasa Indonesia yang bertujuan utama meningkatkan kompetensi komunikasi siswa penggunaan OHP akan mempermudah siswa menerima pelajaran yang diuraikan guru secara lisan. Aksioma yang harus dikuasai serta contoh-contohnya dapat divisualisasikan melalui media OHP dengan lebih baik dan bervariasi. Dengan demikian pembangunan kesan dan upaya mengurangi salah interprestasi siswa terhadap bahan ajar dapat dikurangi.

\section{Pembahasan Hasil Analisis Hipotesis Penelitian Kelima}

Kesimpulan analisis hipotesis kelima adalah ada perbedaan yang signifikan pada hasil belajar Bahasa Indonesia siswa metode ceramah disertai LKS dengan siswa metode ceramah tanpa 
disertai LKS. Dengan kata lain, penelitian ini membuktikan bahwa penggunaan LKS dalam metode ceramah mempengaruhi hasil belajar Bahasa Indonesia siswa. Sama dengan pada pelajaran PPKn, pengaruh penggunaan LKS dalam pembelajaran Bahasa Indonesia bersifat positif. Geriach (1971) menyatakan bahwa LKS mempunyai peranan amat penting dalam upaya mencapai tujuan pembelajaran.

Pengaruh positif penggunaan LKS ini dapat dijelaskan dari pemahaman bahwa unsur utama strategi pembelajaran adalah terjalinnya interaksi positif guru-siswa yang dapat terbangun melalui penggunaan LKS. Selama ini,LKS sudah menjadi salah satu alternatif dalam strategi belajar mengajar Bahasa Indonesia yang dilaksanakan di sekolah. Sama dengan pada pelajaran PPKn, LKS berfungsi sebagai arahan kegiatan siswa dalam mengikuti proses pembelajaran dan sebagai buku catatan siswa,menjadi prasarana komunikasi yang memungkinkan guru memberitahukan hasil kerja siswa dalam mengerjakan latihan, dan siswa menjadi tahu telah mencapai tujuan. Pembahasan Hasil Analisis Hipotesis Penelitian Keenam

Tidak ada interaksi antara metode ceramah bermedia OHP dengan metode ceramah disertai LKS dalam hasil belajar Bahasa Indonesia siswa. Hal ini berbeda dengan pada pelajaran PPKn. Namun demikian, masing-masing alat bantu secara sendiri-sendiri memiliki pengaruh positif terhadap hasil belajar siswa.

Pada akhirnya, secara ringkas dapat disampaikan bahwa media OHP dan LKS, baik digunakan secara terpisah ataupun secara bersama-sama, terbukti dapat mempengaruhi hasil belajar PPKn dan Bahasa Indonesia siswa. Hal ini disebabkan kedua media tersebut memiliki beberapa kelebihan yang mampu meningkatkan motivasi belajar siswa, keterlibatan dalam proses pembelajaran siswa, dan memperjelas materi bahasan.

\section{KESIMPULAN DAN SARAN}

Berdasarkan hasil pembahasan yang telah diuraikan maka penelitian ini menghasilkan kesimpulan sebagai berikut.

1. Ada perbedaan yang signifikan pada hasil belajar PPKn dan Bahasa Indonesia kelompok siswa metode ceramah bermedia OHP dan siswa metode ceramah tanpa media OHP.

2. Ada perbedaan yang signifikan hasil belajar PPKn dan Bahasa Indonesisa siswa metode ceramah disertai LKS dan siswa metode ceramah tanpa disertai LKS.

Ada interaksi antara metode ceramah bermedia OHP dan metode ceramah disertai LKS dalam hasil belajar PPKn.

Adapun saran dapat disampaikan berkenaan dengan hasil penelitian ini adalah untuk meningkatkan penggunaan media OHP dan LKS dalam pembelajaran dalam rangka meningkatkan motivasi belajar siswa, yang pada akhirnya diharapkan dalam bentuk meningkatnya prestasi belajar secara optimal.

\section{REFERENSI}

Arikunto, S. (1992). Prosedur penelitian. Bandung: Penerbit Sinar Baru Algesindo.

Briggs, M. L. (1986). Learning theory for teacher. Harper and Raw. Publiser.

Darmojo, H., \& Kalligis. J. R. E. (1993). Pendidikan IPA 2. Departemen Pendidikan dan Kebudayaan Pendidikan Tinggi Proyek Pembinaan Tenaga Kependidikan. Jakarta.

Degeng. I. N. S. (1989). Ilmu pengajaran dan taksonomi variabel. Jakarta: Depdikbud Dirjen Dikti P21.PTK. 
Gerlach. E., (1971). Teaching and media a systematic approach by prentice hall. Inc. New Jersey: Englewood Cliffs.

Hamalik, O. (1989). Media pendidikan. Penerbit: Citra Aditya Bakti. Bandung

Harun, R. (1984). Cara membuat transparansi. Penerbit: Dep. Pertanian Balai Informasi Lembang. Jawa Barat.

Heinich, M., \& Russel. (1982). Instructional media and the new technology and instruction. John Wiley an Sons. New York.

Nur M. (1994). Pengembangan model PBM IPB berorientasi PKP untuk meningkatkan daya nalar dalam rangka menyongsong masyarakat IPTEK pada Pembangunan jangka panjang tahap kedua. Makalah disajikan dalam seminar nasional hasil penelitian pendidikan MIPA III. IKIP Ujung Pandang 25-27 Juli 1995.

Prayitno. E. (1989). Motivasi dalam belajar. Penerbit: Depdikbud Dirjen Dikti P2LPTK. Jakarta.

Setijadi. (1987). Pemilihan dan pengembangan media untuk pembelajaran. Penerbit: Rajawali. Jakarta. 